\title{
PENGARUH MODEL PEMBELAJARAN KOOPERATIF TIPE NUMBERED HEAD TOGETHER TERHADAP HASIL BELAJAR PASSING BOLA VOLI
}

\author{
Ni Nengah Ari Yustika Sari ${ }^{1}$, I Putu Panca Adi $^{2}$, I Made Satyawan ${ }^{3}$ \\ ${ }^{1,2,3}$ Fakultas Olahraga dan Kesehatan \\ Universitas Pendidikan Ganesha \\ Singaraja, Indonesia \\ Email : ariyustika12@gmail.com ${ }^{1}$, drsputupancaadi@gmail.com² \\ made.satyawan@undiksha.ac.id ${ }^{3}$
}

\begin{abstract}
ABSTRAK
Penelitian ini bertujuan mengetahui pengaruh model pembelajaran kooperatif tipe numbered head together terhadap hasil belajar passing bola voli pada peserta didik kelas $X$ SMKS Pariwisata Triatma Jaya Singaraja. Jenis penelitian ini adalah eksperimen sesungguhnya dengan menggunakan rancangan penelitian posttest only control grup design. Populasi dari penelitian ini adalah peserta didik kelas X SMKS Pariwisata Triatma Jaya Singaraja yang berjumlah 236 orang, yang kemudian dipilih sebagai sampel penelitian sebanyak 60 orang (30 orang dari kelas X kuliner 1 dan 30 orang dari kelas $X$ kuliner 2). Teknik pengambilan sampel dilakukan dengan simple random sampling. Data hasil belajar dikumpulkan melalui tes kognitif dan psikomotor. Analisis data menggunakan Uji-t dengan bantuan SPSS 16.00 for windows. Pada kelompok eksperimen diperoleh nilai rata-rata 80,33 , sedangkan kelompok kontrol 76,10 Berdasarkan Uji Independent Sampel Test angka signifikan yang diperoleh melalui uji-t adalah sig $0.000<0,05$. Jadi dapat disimpulkn model pembelajaran kooperatif tipe numbered head together berpengaruh signifikan terhadap hasil belajar bola voli. Dengan demikian disarankan kepada guru PJOK dapat menerapkan model kooperatif tipe numbered head together karena sudah terbukti berpengaruh terhadap peningkatan hasil belajar peserta didik.
\end{abstract}

Kata kunci: NHT, Hasil Belajar, Bola Voli

\section{ABSTRACT}

The aimed of this reseach to determine the effect of the Numbered Head Together cooperatif learning model on volleyball passing learning outcomes in class $X$ students of SMKS Pariwisata Triatma Jaya Singaraja. The type of this research is an actual exsperiment using a posstest only control grup design. The populations of this research were 236 students of SMKS Pariwisata Triatma Jaya Singaraja, which were then selected as 60 research samples that are ( 30 student from class X kuliner 1 and 30 student from class $\mathrm{X}$ kuliner 2 ). The techque sampling is done by simple random sampling. The learning outcomes data were collected through by cognitive and psychomotor test. The analysis data using Uji-t with helping by SPSS 16.00 for windows. In the exsperimental group obtained an average scor are 80.33, while the control group 76.10. based om the Independent Sample Test the 
significant number obtained thruogh the Uji-t was sig $0,00<0.05$. Because of that it can be concluded type of the Numbered Head Together cooperative learning model has a significant efect on volleyball learning outcomes. Thus it is recommended that PJOK teachers can apply the Numbered Head Together cooperative learning because it has been proven to have an effect on improving student learning outcumes

Keywords: NHT, Learning outcomes, Volleyball

\section{PENDAHULUAN}

Pendidikan adalah usaha sadar
dan terencana untuk mewujudkan
suasana belajar dan proses pembelajaran
agar peserta didik secara aktif
mengembangkan potensi dirinya untuk
memiliki kekuatan spritual keagamaan,
pengendalian diri kepribadian,
kecerdasan, ahlak mulia, serta
keterampilan yang diperlukan dirinya,
masyarakat, bangsa, dan negara.
Pendidikan Jasmani Olahraga dan
Kesehatan merupakan bagian yang
sangat penting bagi proses pendidikan
yang melibatkan interaksi antara peserta
didik dengan lingkungan yang dikelola
melalui aktivitas jasmani secara
sistematik menuju pembentukan manusia
suutuhnya.
Menurut Dimyati dan Mudjiono (2006:3) Hasil belajar merupakan hasil dari suatu interaksi tindak belajar dan tindak mengajar. Menurut Suprijono (2009:5) hasil belajar adalah pola-pola perbuatan, nilai-nilai, pengertianpengertian, sikap-sikap, apresiasi dan keterampilan. Dengan demikian dapat disimpilkan hasil belajar merupakan suatu hasil yang diperoleh peserta didik dari proses belajar, pola perbuatan dan sikap.

Pembelajaran merupakan aspek kegiatan manusia yang kompleks yang tidak sepenuhnya dapat dijelaskan. Pembelajaran secara singkat dapat diartikan sebagai produk interaksi berkelanjutan antara pengembangan pola hidup (trianto:17). Menurut Dimyanti dan Mudjiono (2006:157) pembelajaran adalah proses yang diselenggarakan oleh guru untuk membelajarkan peserta didik dalam belajar bagaimana belajar memperoleh dan di proses pengetahuan, keterampilan, dan sikap. Dari uraian diatas dapat disimpulkan bahwa pembelajaran merupakan suatu proses interaksi antara peserta didik dan pendidik dengan mengembangkan pengetahuan, sikap, dan keterampilan untuk mencapai tujuan yang diharapkan.

Menurut Joyce (dalam Trianto, 2007:5) model pembelajaran merupakan suatu perencanaan atau pola yang digunakan sebagai pedoman dalam merencanakan pembelajaran di kelas dan untuk menetukan perangkat-perangkat pembelajaran termasuk didalamnya bukubuku, komputer, kurikulum dan lain-lain. Model pembelajaran kooperatif tipe NHT merupakan pembelajaran yang dirancang untuk mempengaruhi interaksi peserta dididk (trianto, 2007:62). NHT sangat cocok untuk pembelajaran PJOK karena dalan pembelajaran ini peserta didik satu dengan yang lain saling membantu apabila ada kesulitan. Jadi, model pembelajaran kooperatif tipe $\mathrm{NHT}$ adalah adalah model pembelajaran yang mengorganisasikan peserta didik dalam kelompok belajar secara heterogen dan diberi nomor yang berbeda sesuai jumlah anggota kelompok yang dirancang untuk mempengaruhi pola interaksi peserta didik, memberikan kesempatan untuk saling berbagi pendapat dan bertanggung jawab terhadap hasil kerjanya yang memiliki tujuan untuk meningkatkan penguasaan peserta didik.

Model pembelajaran konvensional adalah model pembelajaran tradisoanal 
atau disebut juga model ceramah, karena sejak dahulu model ini telah dipergunakan sebagai alat komunikasi lisan guru dengan anak didik dalam proses belajar mengajar. Guru menganggap bahwa karena murid-muridnya duduk dengan dian dan mendengarkan pembicaraan, mereka itu sedang belajar (Suryosubroto, 2009:157).

Hasil penelitian yang relevan terkait penelitian ini adalah penelitian yang dilakukan Aryawan yang menenukan model pembelajaran kooperatif tipe NHT berpengaruh signifikan terhadap hasil belajar passing bola voli pada peserta didik kelas VIII SMP Negeri 2 Singaraja tahun pelajaran 2016/2017.

Permainan bola voli merupakan suatu permainan yang kompleks yang tidak mudah dilakukan oleh setiap orang. Sebab, dalam permainan bola voli dibutuhkan koordinasi gerak yang benarbenar disa diandalkan untuk melaksanakan sumua gerakan yang ada dalam permainan bola voli. Dalam permainan bola voli ada beberapa bentuk teknik dasar yang harus dukuasai yang terdiri dari servis, passing (passing atas dan passing bawah), blok, dan smash (Nuril, 2017:20). Dalam penelitian ini teknik dasar yang akan diteliti adalah passing atas dan passing bawah dimana passing ini dilakukan dengan sikap awalan, pelaksanaan, dan akhiran. "Passing adalah mengoper bola pada teman sendiri dalam satu regu dengan suatu teknik tertentu sebagai langkah awal untuk menyusun pola seragam kepada regu lawan" (Yunus 1992:122) "Passing lebih ditekankan untuk menerima dan mengoperkan bola kepada teman seregunya" ( Danu Budhiarta, 2008 :31). Passing adalah pukulan bola pertama setelah bola itu berada dalam permainan akibat dari serangan service lawan atau permainan net (Aryawan, 2016). Berdasarkan uraian diatas passing merupakan bagaian yang sangat penting dalam permainan bola voli. Oleh karena itu dalam belajar keterampilan bola voli teknik dasar passing yang harus dikuasi pertama kali untuk memepermudah melakukan operan kepada team atau teman. Teknik dasar passing dalam permainan bola voli ada dua yaitu passing atas dan passing bawah.

Berdasarkan nilai ulangan haruan passing bola voli di kelas $X$ SMKS Pariwisata Triatma Jaya Singaraja hasil belajar peserta didik secara keseluruhan masih rendah, berdasarkan pedoman pada konversi nilai mata pelajaran PJOK ketuntasan secara individu kelas $X$ di SMKS Pariwisata Triatma Jaya Singaraja adalah 75. Hasil belajar kelas $X$ di SMKS Pariwisata Triatma Jaya Singaraja yang terdiri dari 8 kelas dengan jumlah 236 peserta didik yang nilainya tuntas sebanyak 48 orang (20\%) dan peserta didik yang tidak tuntas berjumlah 188 orang $(80 \%)$ dari hasil belajar materi bola besar (bola voli-passing atas dan passing bawah).

$\begin{array}{ccc}\text { Keberhasilan pembelajaran } & \text { PJOK } \\ \text { salah satunya dipengaruhi oleh }\end{array}$
kompetensi guru dalam mendidik, mengajar, membimbing, mengarahkan, serta mengevaluasi peserta didik. pembelajaran dikatakan berhasil bilamana siswa mampu terlibat secara tepat dan aktif dalam proses pembelajaran serta mampu memperoleh kemampuan sesuai dengan tujuan pembelajaran (Astrini, 2015)

Untuk mencapai keberhasilan dalam proses pembelajaran guru dituntut untuk memiliki pengetahuan dan pemahaman yang baik mengenai metode dan model pembelajaran yang sesuai dengan karakteristik peserta didik agar tercipta proses belajar mengajar yang aktif, inovatif, kreatif, efektif, dan menyenangkan.

Pemecahan permasalahan seperti ini, cara yang tepat digunakan iyalah dengan mengubah model pembelajaran kooperatif tipe numbered head together. Pembelajaran NHT atau pemikiran bersama adalah jenis pembelajaran yang 
dirancang untuk memepengaruhi pola interaksi peserta didik dan sebagai alternatif terhadap struktur kelas tradisional (Trianto 2007:62). Melalui model pembelajaran ini peserta didik akan dibagi kedalam kelompok yang beranggotakan 3-5 orang dan setiap anggota kelompok diberikan nomor 1-5, lalu guru PJOK memanggil salah satu peserta didik yang dianggap mampu melakukan gerakan untuk menjelaskan materi yang telah mereka pahami, dan guru PJOK memberikan pertanyaan kepada peserta didik yang nantinya peserta didik akan berfikir bersama untuk menyatukan pendapat dan mampu memberikan jawaban atas pertanyaan yang diberikan oleh guru PJOK, setelah itu guru PJOK memanggil satu nomor tertentu kemudian peserta didik yang nomornya sesuai mangacungkan tangannya dan mencoba menjawab pertanyaan untuk semua kelas. Kelebihan model pembelajaran kooperatif NHT adalah (1) mendorong dan mengkondisikan perkembangan sikap dan keterampilan sosial peserta didik, serta meningkatkan hasil belajar, (2) mengedepankan penerimaan perbedaan terhadap individu, (3) dengan waktu sedikit dapat menguasai materi secara mendalam.

Tujuan dari penelitian ini adalah untuk mengetahui pengaruh model pembelajaran kooperatif tipe NHT terhadap hasil belajar teknik dasar passing bola voli pada peserta didik kelas $X$ SMKS Pariwisata Triatma Jaya Singaraja tahun pwlajaran 2019/2020.

\section{METODE PENELITIAN}

Jenis penelitian yang digunakan dalam penelitian ini adalah eksperimen sesungguhnya atau eksperimen murni. "Penelitian eksperimen sesungguhnya bertujuan untuk menyelidiki kemungkinan saling berhubungan sebab-akibat dengan cara mengenakan kepala satu atau lebih kelompok eksperimental satu atau lebih kondisi perlakuan

dan memperbandingkan hasilnya dengan satu atau lebih kelompok kontrol yang tidak dikenal kondisi perlakuan"(Kanca, 2010:86). Rancangan pada penelitian ini adalah posstest only control grup design.

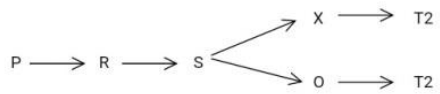

Gambar 1. Rancangan Penelitian Posttest Only Control Grup Design

(Kanca, 2010:87)

Keterangan:

$$
\begin{array}{ll}
\mathrm{P} & =\text { Populasi } \\
\mathrm{R} & =\text { Random } \\
\mathrm{S} & =\text { Sampel } \\
\mathrm{T} 2 & =\text { Tes Akhir (posttest) } \\
\mathrm{X} & =\text { Kelompok Eksperimen } \\
\mathrm{O} & =\text { Kelompok Kontrol }
\end{array}
$$

Dalam penelitian ini yang menjadi populasi adalah seluruh peserta didik kelas X SMKS Pariwisata Triatma Jaya Singaraja tahun pelajaran 1019/2020 yang terbagi menjadi 8 kelas. Dalam penentuan sampel peneliti menggunakan teknik simple random sampling. Yang menjadi sampel dalam penelitian ini adalah peserta didik kelas $\mathrm{X}$ kuliner 1 dengan jumlah 30 orang sebagai kelompok kontrol dan $\mathrm{X}$ kuliner 2 dengan jumlah 30 orang sebagai kelompok eksperimen.

Prosedur pengumpulan data dilakukan dengan memberikan perlakuan dan tes akhir (posttest) setelah perlakuan. Tes diberikan kepada kelompok eksperimen dan kelompok kontrol dengan Kompetensi pengetahuan berupa tes tulis objektif, dan kompetensi keterampilan dinilai menggunakan tes unjuk kerja.

Jenis instrumen yang digunakan adalah asesmen teknik dasar passing bola voli . Data tentang hasil belajar peserta didik dilakukan dengan menggunakan instrumen berupa asesmen hasil belajar teknik dasar passing bola voli. 
Sebelum dilakukan pengujian untuk mendapatkan simpulan, data yang diperoleh perlu diuji normalitas dan homogenitasnya setelah itu dilanjutkan: Analisis data pada penelitian ini akan menggunakan bantuan program SPSS 16.0 for Windows.

\section{HASIL DAN PEMBAHASAN}

Rangkuman analisis terhadap data hasil belajar teknik dasar passing bola voli pada kelompok eksperimen dan kelompok kontrol tercantum pada Tabel 1 berikut.

Tabel 1. Rangkuman Data Hasil Belajar Bola Voli (Passing Atas dan Passing Bawah)

\begin{tabular}{lcc}
\hline \multicolumn{1}{c}{ Variabel } & Kelompok Eksperimen & Kelompok Kontrol \\
\hline Banyak siswa & 30 orang & 30 orang \\
Rata-rata Posttest & 80,33 & 76,10 \\
\hline
\end{tabular}

Berdasarkan data tentang hasil belajar materi bola besar (bola volipassing atas dan passing bawah) kelompok eksperimen dan kelompok kontrol dengan jumlah masing-masing 30 orang diperoleh nilai kelompok eksperimen 80,33 sedangkan untuk kelompok kontrol 76,10. Sehingga dapat disimpulkan peningkatan yang lebih

Tabel 2. Hasil Uji Normalitas Sebaran Data signifikan terdapat pada kelompok eksperimen dengan kenaikan nilai yang jauh lebih besar dibandingkan dengan kelompok kontrol.

Pengujian normalitas sebaran data dilakukan untuk meyakinkan bahwa subjek penelitian berdistribusi normal yang tercantum pada Tabel 2 .

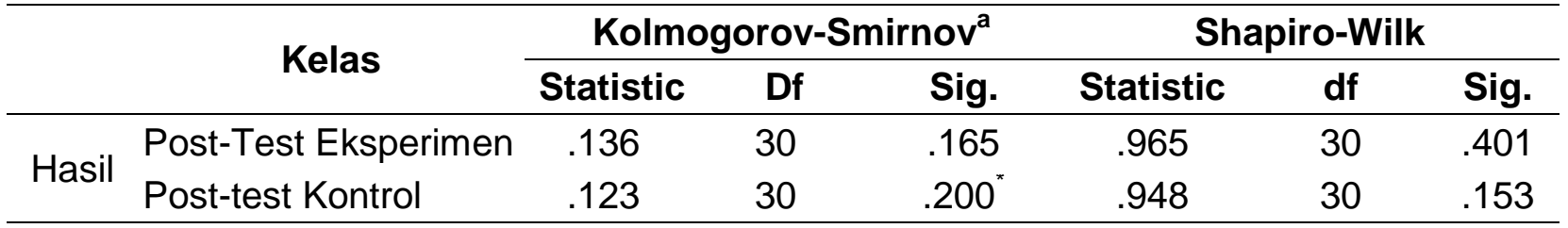

Berdasarkan tabel tersebut terlihat bahwa untuk semua variabel signifikasi pada uji Kolmogorov-Smirnov lebih besar dari 0,05 dengan rincian signifikasi kelompok exsperimen 0,165 dan kelompok kontrol 0,200. Dengan demikian semua sebaran data berdistribusi nornal.

Uji homogenitas varian dilakukan dengan pengelompokan berdasarkan model pembelajaran kooperatif NHT dengan model pembelajaran konvensional. Uji homogenitas varian antar kelompok dilakukan dengan bantuan SPSS 16.00 for windows dengan menggunakan Levene's Test Of Equality Eror Variance. Hipotesis statistik yang diuji dalam pengujian homogenitas adalah sebagai berikut:

$H_{0}$ : variansi pada setiap kelompok adalah sama (homogen)

$H_{a}$ : variansi pada setiap kelompok tidak sama (tidak homogen)

Dengan kriteria pengujian yang digunakan adalah terima $H_{o}$ jika nilai sig $>$ 0.05 dimana data memiliki varians yang sama apabila angka signifikansi yang dihasilkan > 0.05. Rangkuman hasil perhitungan homogenitas data menggunakan SPSS Statistic 16 For Windows dapat dilihat pada Tabel 3. 
Tabel 3. Rangkuman Hasil Uji Homogenitas Varians

\begin{tabular}{cccc}
\hline Levene Statistic & df1 & df2 & Sig. \\
\hline 1.391 & 1 & 58 & .243 \\
\hline
\end{tabular}

Berdasarkan Tabel tersebut hasil uji menunjukan bahwa hasil belajar bola voli (passing atas dan passing bawah) dengan taraf signifikasi 0,243 lebih besar dari 0,05 sehingga dapat ditarik kesimpulan bahwa pada setiap kelompok adalah sama (homogen).

Hipotesis penelitian yang telah dikemukakan dalam kajian teori menyatakan bahwa, terdapat perbedaan hasil belajar teknik dasar passing bola voli pada peserta didik yang dibelajarkan menggunakan model pembelajaran kooperatif tipe NHT dengan peserta didik yang dibelajarkan menggunakan model pembelajaran langsung. Pengujian hipotesis menggunakan uji-t dengan bantuan SPSS 16.0 for Windows.

Tabel 4. Independent Samples Test

\begin{tabular}{|c|c|c|c|c|c|c|c|c|c|c|}
\hline & & \multicolumn{2}{|c|}{$\begin{array}{l}\text { Levene's } \\
\text { Test for } \\
\text { Equality of } \\
\text { Variances }\end{array}$} & \multicolumn{7}{|c|}{ t-test for Equality of Means } \\
\hline & & \multirow[t]{2}{*}{$\mathbf{F}$} & \multirow[t]{2}{*}{ Sig. } & \multirow[t]{2}{*}{$\mathbf{t}$} & \multirow[t]{2}{*}{ df } & \multirow[t]{2}{*}{$\begin{array}{l}\text { Sig. (2- } \\
\text { tailed) }\end{array}$} & \multirow[t]{2}{*}{$\begin{array}{l}\text { Mean } \\
\text { Differe } \\
\text { nce }\end{array}$} & \multirow[t]{2}{*}{$\begin{array}{c}\text { Std. } \\
\text { Error } \\
\text { Differe } \\
\text { nce }\end{array}$} & \multicolumn{2}{|c|}{$\begin{array}{c}95 \% \\
\text { Confidence } \\
\text { Interval of } \\
\text { the } \\
\text { Difference } \\
\end{array}$} \\
\hline & & & & & & & & & Lower & Upper \\
\hline \multirow[b]{2}{*}{ Hasil } & $\begin{array}{l}\text { Equal } \\
\text { variances } \\
\text { assumed }\end{array}$ & 1.391 & .243 & 4.053 & 58 & .000 & 4.233 & 1.045 & 2.142 & 6.324 \\
\hline & $\begin{array}{l}\text { Equal } \\
\text { variances not } \\
\text { assumed }\end{array}$ & & & 4.053 & 56.240 & .000 & 4.233 & 1.045 & 2.141 & 6.326 \\
\hline
\end{tabular}

Berdasarkan tabel diatas diperoleh nilai signifikasi $=0,000$ maka sig<0,05. Hasil inilah yang dijadikan dasar dalam mengambil keputusan. Adapun keputusan yang diambil adalah tolak $H_{0}$ dan terima $H_{a}$. Hasil ini menyatakan bahwa terdapat perbedaan hasil belajar passing bola voli antara peserta didik yang dibelajarkan dengan menggunakan model pembelajaran kooperatif $\mathrm{NHT}$ dengan peserta didik yang dibelajarkan dengan menggunakan model pembelajaran konvensional.
Berdasarkan hasil analisis data yang diperoleh terdapat perbedaan hasil belajar antara peserta didik yang dibelajarkan dengan menggunakan model pembelajaran kooperatif NHT dengan peserta didik yang dibelajarkan dengan menggunakan model pembelajaran konvensional. Perbedaan hasil belajar tersebut dilihat dari rata-rata hasil belajar peserta didik. nilai rata-rata posttest peserta didik yang dibelajarkan dengan menggunakan model pembelajaran kooperatif NHT 80,33 sedangkan nilai rata-rata posttest peserta didik yang di 
belajarkan dengan menggunakan model pembelajaran konvensional 76,10. Ini berarti model pembelajaran kooperatif NHT berpengaruh terhadap hasil belajar bola voli (passing atas dan passing bawah)

Dalam penelitian ini masingmasing kelompok diberikan perlakuan yang berbeda, dimana kelompok eksperimen diberikan pelakuan menggunakan model pembelajaran kooperatif NHT sedangkan kelompok kontrol diberikan perlakuan menggunakan model pembelajaran konvensional. Pembelajaran kooperatif NHT menghendaki peserta didik saling membantu didalam kelompok kecil. Dimana dalam kelompok koopertif NHT berjumlah 3-5 orang dengan menjalankan proses pembelajaran yang inovatif. Sedangkan dalam kelompok kontrol yang diajarkan menggunakan model pembelajaran konvensional menekankan pada guru sebagai pusat informasi dan peserta didik sebagai penerima informasi, situasi kelas sebagianbesar masih berfokus pada guru sebagai sumber utama pengetahuan, serta penggunaan model ceramah sebagai pilihan utama strategi belajar mengajar.

Berdasarkan pengamatan peneliti pada saat pembelajaran berlangsung model pembelajaran konvensional yang diterapkan dikelompok kontrol pada dasarnya telah menuntun peserta didik untuk dapat memehami dan memperhatikan gerakan dengan benar, namun dengan penggunaan metode ceramah dalam penyampaian materi menyebabkan pembelajaran berpusat pada guru dan juga masih banyak peserta didik yang kurang aktif. Hal ini mengakibatkan kurangnya partisipasi peserta didik secara menyeluruh dalam proses pembelajaran atau bisa juga dikatakan hanya peserta didik yang memiliki kemampuan lebih yang mau berpartisipasi aktif, sehingga banyak peserta didik yang kurang memahami materi yang diberikan pada saat proses pembelajaran berlangsung.

Hal ini berbeda dengan pembelajaran pada kelompok eksperimen dengan menggunakan model pembelajaran kooperatif tipe NHT dimana peserta didik dibelajarkan dalam kelompok-kelompok kecil yang heterogen dan setiap anggota kelompoknya diberikan nomor yang akan digunakan guru untuk menunjuk salah satu peserta didik pada masing-masing kelompok untuk menjelaskan hasil diskusi dalam kelompok masing-masing. Hal tersebut dapat memberikan tanggung jawab kepada seluruh anggota kelompok untuk memahami dan menguasai materi yang diajarkan sehingga melibatkan partisipasi dari seluruh peserta didik. faktor-faktor tersebut mengakibatkan pembelajaran yang berlangsung pada kelompok eksperimen mendapat respon yang lebih baik dari peserta didik sehingga rata-rata skor peserta didik pada kelompok eksperimen lebih tinggi daripada rata-rata skor pada kelompok kontrol.

\section{PENUTUP}

Hasil penelitian ini menunjukan bahwa hasil belajar materi bola besar (bola-passing atas dan passing bawah) pada kelompok perlakuan yang diberikan model pembelajaran kooperatif NHT secara signifikan lebih tinggi dari pada kelompok yang diberikan model pembelajaran konvensional. Berdasarkan temuan ini, maka untuk meningkatkan kualitas hasil belajar materi bola besar (bola voli-passing atas dan passing bawah) dapat dilakukan dengan menerapkan model pembelajaran kooperatif NHT. Implikasi dari hasil penelitian ini adalah penerapan model pembelajaran kooperatif NHT hendaknya dapat dikembangkan dan ditingkatkan penggunaannya dalam proses pembelajaran bola voli khususnya passing atas dan passing bawah. penerapan model pembelajran kooperatif 
tipe NHT dalam proses pembelajaran dimaksudkan untuk memebiasakan peserta didik bekerja sama dengan kelompoknya secara aktif dan saling membantu dalam proses pembelajaran, sedangkan jika pembelajaran dengan menggunakan model pembelajaran konvensional peserta didik kurang mengembangkan pola pikirnya, karena pusat pengetahuan ada pada guru yang mengajar. Implikasinya adalah guru harus dapat memilih model pembelajaran yang sesuai dengan karatker peserta didik, salah satunya dengan menggunakan model pembelajaran kooperatif tipe NHT. Berdasarkan hasil analisi data dan pembahasan dapat disimpulkan bahwa penerapan model pembelajaran kooperatif NHT berpengaruh signifikan terhadap peningkatan hasil belajar passing bola voli pada peserta didik kelas $X$ SMKS Pariwisata Triatma Jaya Singaraja tahun pelajaran 2019/2020.

Adapun saran yang dapat diajukan berdasarkan analisis dan pembahasan diatas agar nantinya dapat digunakan dalam proses pembelajaran dan penelitian kedepannya yaitu sebagai berikut. Pertama, Bagi peserta didik, dengan diterapkannya model pembelajaran kooperatif NHT diharapkan mampu meningkatkan hasil belajar peserta didik dalam proses pembelajaran.

Kedua, Bagi guru PJOK model pembelajaran kooperatif NHT dapat dijadikan salah satu alternatif pembelajaran yang dapat diterapkan dikelas. Ketiga, Penelitian ini dilaksanakan pada pokok bahasan materi bola besar (bola voli-passing atas dan passing bawah) kelas X DMKS Pariwisata Triatma Jaya Singaraja, sehingga memperoleh bukti-bukti umum dari penerapan model pembelajaran kooperatif $\mathrm{NHT}$, diharpkan peneliti lain untuk mencoba pada pokok bahasan lain untuk mengetahui pengaruh model pembelajaran kooperatif NHT dalam pembelajaran PJOK secara lebih mendalam Dan keempat, Penelitian ini hanya mengukur ada atau tidaknya pengaruh dari model pembelajaran kooperatif tipe NHT terhadap hasil belajar teknik dasar passing (passing atas dan passing bawah) bola voli tanpa meneliti lebih jauh arah pengaruh yang diberikan. Diwaktu mendatang dapat dilakukan suatu penelitian untuk meneliti sejauh mana arah pengaruh yang diberikan oleh model pembelajaran kooperatif tipe NHT terhadap hasil belajar PJOK peserta didik.

\section{DAFTAR PUSTAKA}

Aryawan, I Ketut Arta, I Gusti Lanang Agung Parwata, I Made Satyawan. 2016. Pengaruh Model Pebelajaran Kooperatif Tipe NHT Terhadap Hasil Belajar Passing Bola Voli. Tersedia pada https://ejournal.undiksha.ac.id/inde x.php/JJP/article/download/11331/ 7242

Bhudiarta, I Made Danu. 2008. Teori Praktik Permainan Bola Voli dan Bola Voli Pantai Singaraja: Universitas Pendidikan Ganesha.

Damyanti dan Mudjiono. 2006. Belajar dan Pembelajaran. Jakarta : Rineka Cipta

Kanca, I Nyoman. 2010. Metodelogi Penelitian Pengajaran Pendidikan Jasmani dan Olahraga. Singaraja: Universitas Pendidikan Ganesha.

Perdana, I Putu Mandi, I Putu Panca Adi, I Made Kusuma Wijaya. 2017. Pengaruh Model Pembelajaran Kooperatif Tipe NHT Terhadap Hasil Belajar Passing Bola Voli Pada Siswa Kelas VII SMP Negeri 1 Sawan. Tersedia pada https://ejournal.undiksha.ac.id/inde x.php/JJP/article/download/14792/ 9059. Diakses pada 3 November 2018.

Nuril. 2007. Panduan Olahraga Bola Voli. EKA PUSTAKA UTAMA. 
Suprijono, A. 2009. Cooperative Learning: Teori dan Aplikasi PAIKEM. Yogjakarta: Pustaka Belajar

Suryosubrota, 2009. Proses belajar mengajar di sekolah. Jakarta Rineka Cipta.

Trianto. 2007. Model-Model Pembelajaran Inovatif

Berorientasi Konstruktif Jakarta Prestasi Pustaka Publisher.

Trianto. 2010. Mendesain Model Pembelajaran Inovatif Progresif. Jakarta: Kencana

Yunus, M. 1992. Olahraga Pilihan Bola Voli. Jakarta:Departemen Pendidikan dan Kebudayaan Direktorat Jendral Pendidikan Tinggi. 